\title{
乾式系吹付けアスベスト無人化 除去・回収システムの開発
}

\section{DEVELOPMENT OF REMOTE SYSTEM TO REMOVE AND COLLECT DRY SPRAYED ASBESTOS}

\author{
森 直樹—— $* 1$ \\ 大山能永—— 3 \\ 長瀬公一—— 2 \\ キーワード : \\ 乾式系吹付けアスベスト，建物解体，ロボット，遠隔操作 \\ Keywords : \\ Dry sprayed asbestos, Building dismantling, Robot, Remote control
}

\section{1.はじめに}

吹付けアスベストは、その防火性や断熱性、吸音性などに優れて いることから、過去において、建物の天井や壁、柱、梁などに吹付 施工等がなされてきた。しかしながら、その後の経年劣化などによ り、その施工面からアスベスト繊維が空気中に浮遊飛散し、肺ガン や中皮腫、石綿肺といった人体の健康に悪影響を与える要因となる ことが指摘されており、有害な吹付けアスベスト等の除去を早急に 行うことが緊急的な命題となっている。その除去方法は、防塵マス クや保護衣を着用した完全防備の専門の作業員が、密閉された室内 に隔離されて、ケレン棒やワイヤーブラシなどを使って吹付けアス ベストを剥離・除去しているのが現状である。これは有害なアス心゙ ストを取り除くという根本的な解決には繋がるものの、作業員が手 作業で除去するということは多大な手間を要し、工事費の高騰を招 いてしまうとともに、作業員の健康被害を引き起こしてしまうこと も懸念される。これは、今後のアスベスト問題の解決に対して大き な障害となる。そこで、我々は石綿含有率が高く、最も有害な乾式 系吹付けアスベストに焦点を当て、その建物解体時における除去・ 回収作業を、遠隔操作によるアスベスト除去ロボットによって安全 かつ効率的に行うことのできるシステムを開発し、模擬アスベスト による実験室での除去・回収実験を行ったので、そのシステム概要 及び実験結果について以下に報告する。また本システムを実際のア スベスト除去工事現場に試験的に導入し、実アスベストによるシス テム実証試験を行ったので、これらの結果もあわせて報告する。

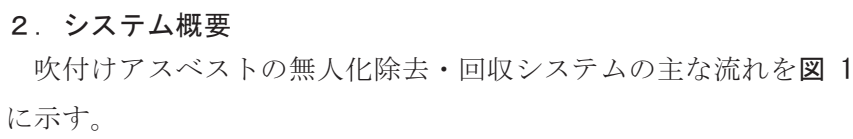

\section{Naoki MORI—— $* 1 \quad$ Koichi NAGASE $-* 2$ Yoshie OYAMA — $* 3$}

We developed a remote system to remove and collect dry sprayed asbestos that consisted of a remote control robot that effectively and safely removed asbestos using jets of water and mixed air. The asbestos was collected in bags that, when filled, were quickly removed by the robot. Laboratory tests confirmed that the system removed and collected asbestos with a high level of safety and efficiency. In addition, we introduced this system into the asbestos removal construction spot for the first time and demonstrated it and examined it.
2. 1 アスベスト除去・回収ロボット

(1) ロボット本体

アスベスト除去・回収ロボットの主な仕様を表 1 に示す。また、 ロボットの外観を写真 1 に示す。

表 1

ロボットの主な仕様

\begin{tabular}{|c|c|}
\hline 全長 & $1,821 \mathrm{~mm}$ (輸送時) \\
\hline 全幅 & $\begin{array}{r}780 \mathrm{~mm} \text { (輸送時) } \\
1,586 \mathrm{~mm} \text { (稼㗢時) }\end{array}$ \\
\hline 全高 & $\begin{array}{l}1,210 \mathrm{~mm} \text { (最低) } \\
3,600 \mathrm{~mm} \text { (取高) }\end{array}$ \\
\hline 重量 & $930 \mathrm{~kg}$ (アタッチメント無) \\
\hline 出力 & $11 \mathrm{~kW}$ \\
\hline 制御 & 有線/無線 \\
\hline
\end{tabular}

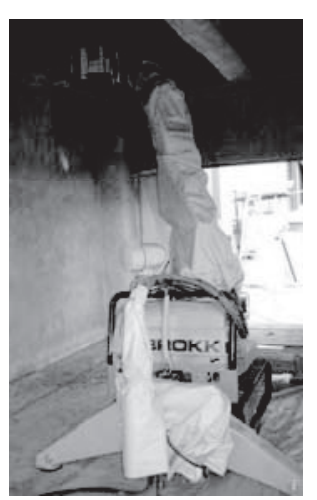

写真 1 ロボット外観
*1 Manager, Taisei Corporation, Technology Center

*2 General Manager, Taisei Corporation, Technology Center

*3 Manager, Taisei Corporation, Building Construction Div.

*2 大成建設(件)技術センター 室言

3 大成建設(株)建築本部 課長 
ロボット本体のベースマシンは遠隔操作が標準装備され、3アーム 構造となっており、吹付けアスベスト除去時の防污対策として専用 の養生カバーを取り付けた。

（2）噴射ノズルスライド装置（乾式吹付けアスベスト除去専用） 建物の各部位に吹付けられているアスベストを剥離・除去するた めに、混気物（高圧水十圧縮空気 + 研削材 + 高分子吸収剂）を同時 噴射することのできるノズルをロボットアームの先端部に装着した。 また、噴射ノズルはアスベスト吹付け面に対して鉛直方向に一定の 斜行角度を持たせて往復移動できるようになっており、更に常時ア スベスト面を削ぎ落とすように、ノズル噴射角度の向きを変えられ るような可変機構を採用した。混気物の主な仕様を表 2 に、噴射ノ ズルスライド装置の外観を写真 2 に示す。

表 2 混気物の主な仕様

\begin{tabular}{|l|l|}
\hline 使用水量 & $5.4 \mathrm{~L} / \mathrm{min}$ \\
\hline 吐出圧力 & $30-140 \mathrm{kgf} / \mathrm{cm}^{2}$ \\
\hline 研削材 & 炭酸力ル㳂、重曹等 \\
\hline 吸水剂 & 高分子吸収剂 \\
\hline
\end{tabular}

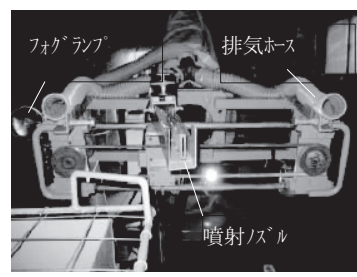

写真 2 噴射ノズル装置の外観

(3) 車載用モニターカメラ

吹付けアスベストの除去・回収を作業区域内で遠隔操作によるロ ボットで行うためのモニターカメラをロボット胴体部分に設置した

(写真 1 参照)。また作業区域内にはロボット作業を監視するための モニターカメラも設置した。モニターカメラの主な仕様を表 3 に、 ロボット作業監視用カメラの外観を写真 3 に示す。

表 3 カメラの主な仕様

\begin{tabular}{|l|l|}
\hline 使用電源 & DC24V $(22 \sim 26 \mathrm{~V})$ \\
\hline 使用温度 & $-15^{\circ} \mathrm{C} \sim+45^{\circ} \mathrm{C}$ \\
\hline ワイパー & 操作指令 $\rightarrow 2$ 往復 \\
\hline 信号形式 & NTSC \\
\hline ズーム比 & $\begin{array}{l}\text { 光学 } 23 \text { 倍 } \\
\text { 電子ズ - - } 44 \text { 倍 } \\
\text { (組合最大 } 92 \text { 倍) }\end{array}$ \\
\hline 旋回角度 & $\begin{array}{l}\text { 水平 } 360^{\circ} \text { エントレス } \\
\text { 垂直 }+30^{\circ} \text { (上向) } \sim \\
-90^{\circ} \text { (真下) }\end{array}$ \\
\hline
\end{tabular}

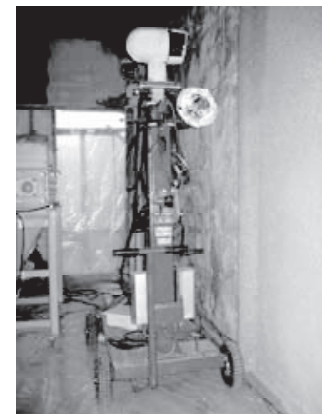

写真 3 作業監視カメラ外観

2. 2 アスベスト回収システム

アスベスト回収システムの概要を図 2 に示す。

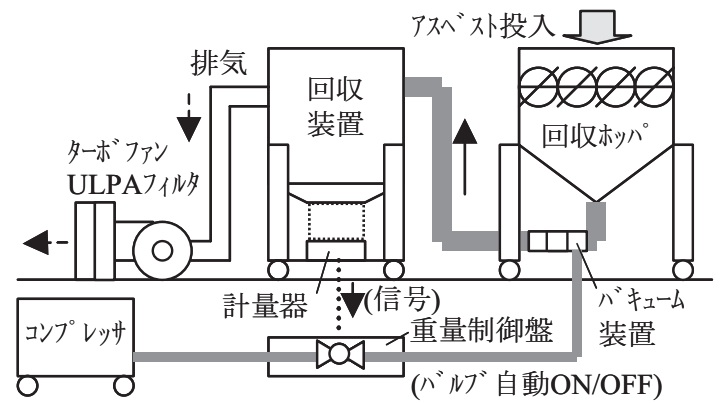

図2 アスベスト回収システム系統図
(1) 回収ホッパー

ロボット付属のブレードにより収集されたアスベストを、所定の 回収袋に吸引・圧送するための回収ホッパーを設置した。回収ホッ パーの投入口には、ロボットにより剥離・除去された塊状のアスベ ストを粉砕するための回転ロール式の破砕装置を組み込んだ。回収 ホッパーの外観を写真 4 に、破砕装置を写真 5 に示す。

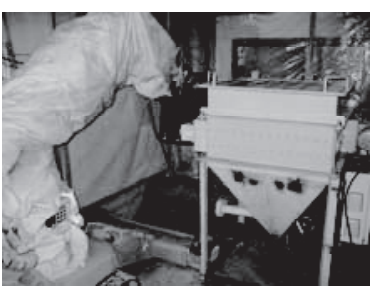

写真 4 回収ホッパー外観

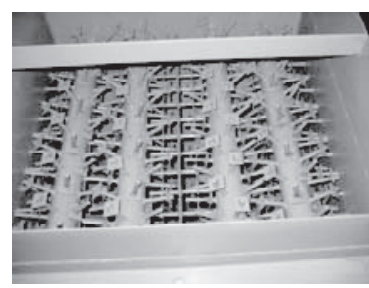

写真 5 破砕装置
（2）バキューム装置

アスベストを回収ホッパーからホース吸引・圧送するためのバキ ユーム装置を回収ホッパー排出部分に取り付けた。バキューム装置 の外観を写真 6 に示す。

(3) 回収装置

圧送されたアスベストを所定の回収袋に重量制御によって一定量 袋詰め（1 重）するための装置を設置した。回収装置の外観を写真 7 に示す。

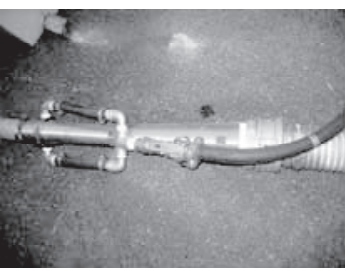

写真 6 バキューム装置外観

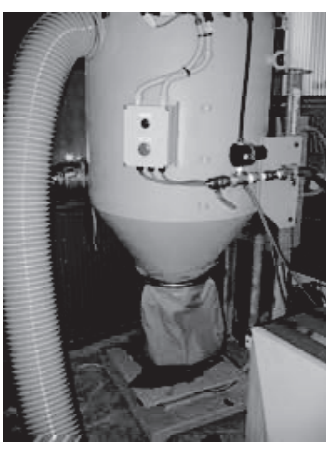

写真 7 回収装置外観

\section{3. 実験概要}

アスベスト無人化除去・回収システムの除去・回収性能について、 実験施設での実証実験を行った。

(実験期間：2006 年 10 月～2007 年 2 月)

\section{1 実験施設}

実験施設は $6.7 \mathrm{~m} \times 3.9 \mathrm{~m} \times 3.4 \mathrm{~m}$ の鉄骨造である。施設内の H 鋼梁・ 柱部分：45mm 厚、他の天井・壁部分：15mm 厚で模擬アスベスト（ロ ックウール）の吹付け工事を行い、約 1 ケ月の養生期間を経た後に 実験を行った。

\section{2 実験結果、及び考察}

（1）アスベスト除去・回収ロボットの除去性能

ロボットの遠隔操作による噴射ノズルの往復移動速度は、概ね 5 〜 $6 \mathrm{~cm} / \mathrm{sec}$ であり、壁面等の単純な模擬アスベスト（ロックウール） 面 (15mm 厚) の場合は、噴射ノズルを 0.5 往復（片道移動）させた だけで、瞬時に縦 $10 \mathrm{~cm}$ 程度の帯状の下地面が現れ、模擬アスベスト を容易に除去できることが確認できた。これを単位時間当りの除去 面積に換算すると約 $18 \sim 22 \mathrm{~m}^{2} / \mathrm{h}$ となり、実際には板状に削ぎ剥が 
される効果も期待できることから、凡そ $20 \mathrm{~m}^{2} / \mathrm{h}$ 以上の除去性能が 期待できるものと考える。しかし、梁部等の $\mathrm{H}$ 鋼面（45mm 厚）の場 合は、噴射ノズルを 2 往復以上横行させないと下地面が現れて来ず、 また凹凸面であることから噴射ノズルスライド装置の位置を調整す る必要があり、現状では約 4 $5 \mathrm{~m}^{2} / \mathrm{h}$ 程度になるものと推定される。 ロボット遠隔操作による $\mathrm{H}$ 鋼面除去後の状況を写真 8 に示す。

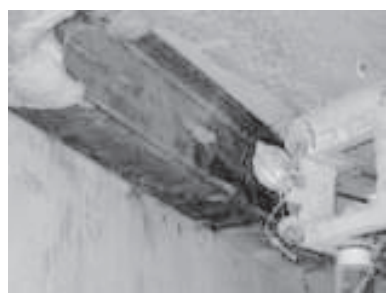

写真 8 除去後のH鋼梁面の状況

\section{（2）高分子吸収剂の同時噴射による吸水性能}

噴射ノズルから高分子吸収剂を同時噴射させることによって床面 に水が溜まる現象等は確認されず、バキューム装置による吸引時に おいても、水と分離することなく、パサパサの状態で円滑に回収袋 までホース吸引・圧送されることが確認できた。

\section{（3）アスベスト回収システムの重量制御の信頼性}

回収装置によってアスベストを $10 \mathrm{~kg}$ 設定で袋詰めした場合の実 際の回収袋重量との差異を図 3 に示す。図3より、設定值に対して $-1.3 \mathrm{~kg}$ から+4. $5 \mathrm{~kg}$ の誤差があることが判る。れは回収装置内部で のアスベスト滞積防止用として加圧ノッキングをする際に、衝撃で 計量器が感知してしまうことに起因しているものと推測され、加圧 時のダンパー調整等の対策が今後必要であることが判った。

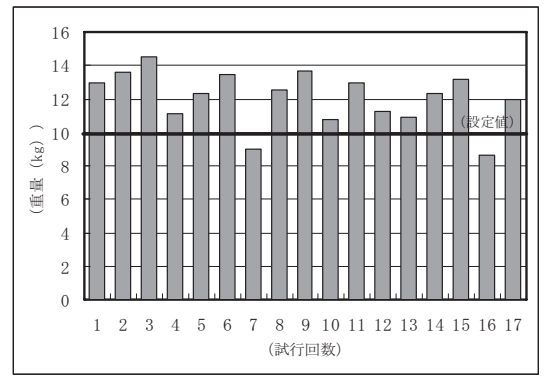

図３アスベスト回収袋の重量制御の精度

\section{4. 建築現場への適用}

\section{1 適用現場の概要}

\section{(1) 工事名称}

H倉庫解体に伴うアスベスト除去工事（仮称）

\section{（2）工事場所}

東京都中央区晴海 4 丁目（写真 9 参照）

\section{(3) 工事期間}

2007 年 10 月 1 日 2007 年 10 月 31 日

(準備及び片付け期間含む)

\section{(4) 工事内容}

既存建物（倉庫）の解体に伴い、アスベスト含有吹付け材の撤去 を行った。(除去対象部位：天井・梁部分 (写真 10 参照) )

\section{(5) 施工範囲図}

施工範囲図を図 4 に示寸。(ロボット除去 : 2 階 3 工区)

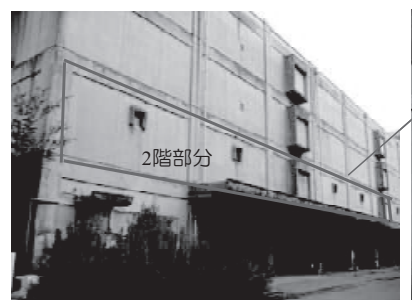

写真 9 適用現場の外観

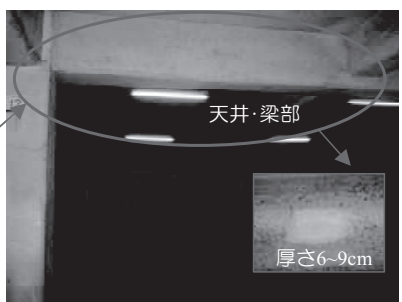

写真 10 適用現場内観

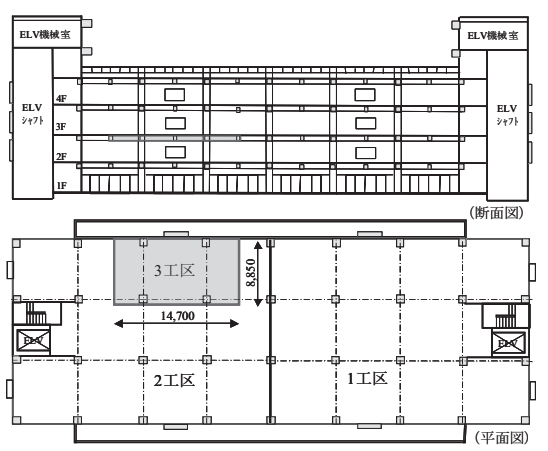

図４ロボットによる除去施工範囲

（6）アスベスト含有吹付け材除去数量

対象とした施工範囲におけるアスベスト除去数量は、天井、梁吹 付け面：175m2（クリソタイル）であった。

（7）アスベスト除去・回収作業の流れ

現場での作業工程を図 5 に示す。作業終了後のロボット装置類は、 セキュリティゾーンにて十分な清掃を行い、エアシャワーを通過さ せて付着物の無いことを確認後、相包・搬出した。

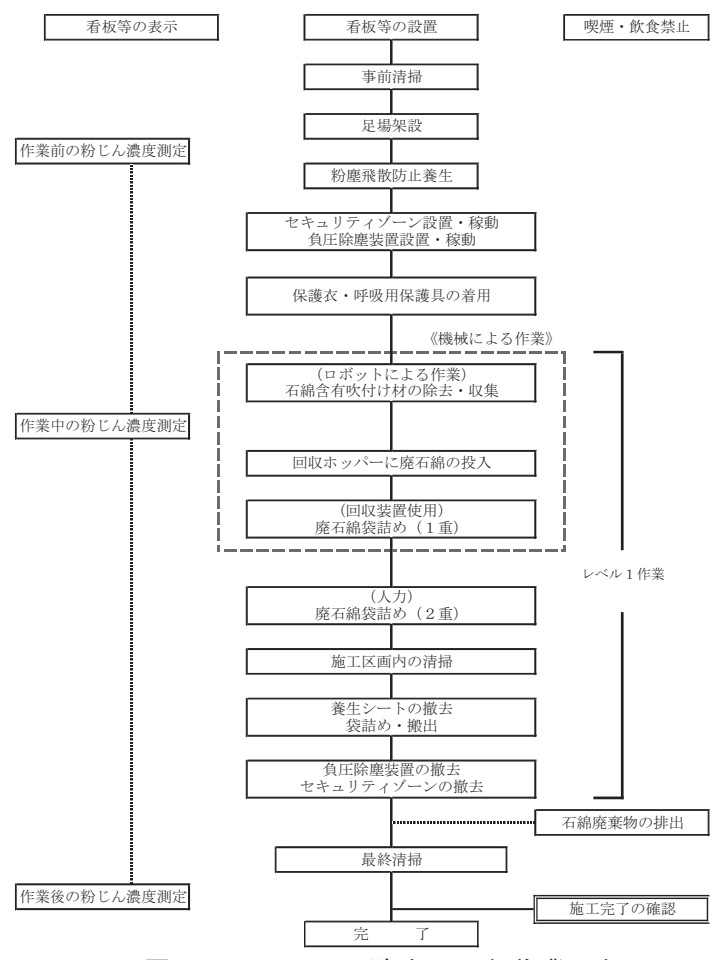

図 5 アスベスト除去・回収作業工程 
（８）システム系統（配線・配管類）

現場でのロボット装置類廻りの配線・配管系統を図 6 に示す。

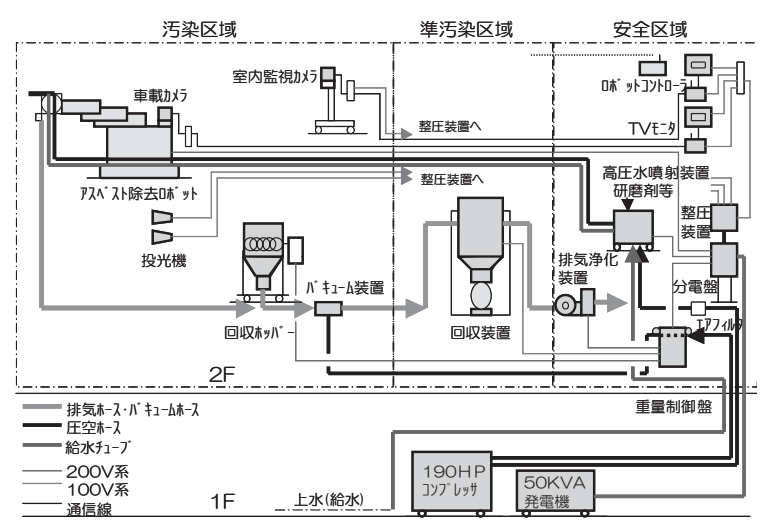

図 6 適用現場でのシステム系統図

\section{2 施工結果、及び考察}

（1）遠隔操作によるアスベスト除去・回収ロボットの除去性能 ロボットによるアスベスト除去作業状況、及びアスベスト除去前 後の天井面の状況を、写真 11 及び写真 12 に示す。(写真 12 にお いて、表面が薄緑になっているのは、塗装面の残痕であって、既に アスベストは剥がれ落ちており、濃いグレ一部分は下地の塗装面を も剥がしている状態であることを示す。）

遠隔操作によるアスベスト除去・回収ロボットを使った乾式系吹 付けアスベストの除去速度は、実アスベスト吹付け材厚み： 6 $9 \mathrm{~cm}$ の天井面に対して、概ね、約 $12 \mathrm{~m} 2 / \mathrm{h}$ （換算值）程度であった。これ は、従来の作業員（人）による除去速度の $2 \sim 3$ 倍程度に相当する ものと推測される。

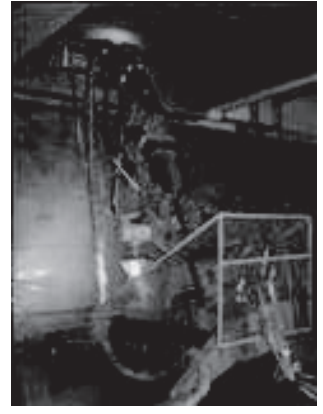

写真 11 除去作業状況

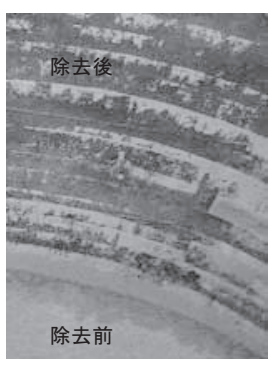

写真 12 除去前後の天井面

\section{（2）ロボットブレードによる床面アスベストの掻き寄せ作業}

アスベスト除去・回収ロボットのアーム先端部に取り付けられた 噴射ノズルからの混気物により剥離・除去され、床面に散乱した塊 状アスベストは、ロボットに付属されているブレードによって、回 収ホッパー近傍の所定の位置まで遠隔操作により円滑に掻き寄せら れ、収集できることが実証できた。また、噴射ノズルからの高分子 吸収剂による吸水効果によって、作業床面が水浸しになる現象は見 られなかった。

\section{（３）ロボットバケットによる塊状アスベストの回収作業}

アスベスト除去・回収ロボットのアーム先端部に取り付けられて いた噴射ノズルスライド装置をバケットに付け替えて、床面に収集 された塊状アスベストを回収ホッパーの投入口まで掻き揚げ、遠隔
操作によって円滑に投入できることが実証できた。

（4）バキューム装置及び回収装置によるアスベストの袋詰作業 アスベスト除去・回収ロボットにより回収ホッパーに投入された 塊状アスベス卜は、破砕装置によって細かく砕かれ、ホースで連結 されているバキューム装置によって、回収装置にセットされた所定 の廃棄袋 $(1$ 重目) に高速で吸引・袋詰めできることが実証できた。

5.まとめ

建物解体時における乾式系吹付けアスベストの無人化除去・回収 システムを開発し、実験施設での模擬アスベスト（ロックウール） によるアスベスト除去・回収ロボットの除去実験を行い、建物部位 及び吹付け厚等により異なるものの、壁面の比較的アスベスト厚み の少ない場所においては、高速で剥離・除去できることが実験的に 立証できた。また、回収システム装置類も円滑に稼動できることを 確認することができた。そして、これらの実験的な見地をもとにし て、本システムを初めて実際のアスベスト除去工事現場に導入して 実証試験を行い、アスベスト除去作業区域外からの遠隔操作による ロボットを使ったアスベスト除去性能を把握することができ、さら に、アスベスト回収システム装置類が実アスベストでも正常に稼動 することを実証することができた。これによって、遠隔操作による ロボットを使って、アスベストを除去・回収できることが現場レベ ルで検証することができた。今後は、実際のアスベスト除去工事現 場での適用を継続して行い、作業員（人）が危険な吹付けアスベス 卜除去作業区域内に入ることを極力少なくし、アスベスト除去コス トや工期等を精查しながら、本格的な実用化に結び付けてゆく所存 である。

\section{6. あとがき}

本研究開発は、平成 18 年度 NEDO 委託事業「緊急アスベスト削 減実用化基盤技術開発」及び平成 19 年度同事業の NEDO 継続研究 の一部によるものです。また、本研究開発を進めるにあたり、多大 なる御指導及び情報の提供を賜りました、「独立行政法人建築研究所 材料研究グループ長・建築生産研究グループ長 本橋健司様」「財団 法人ベターリビング 筑波建築試験センター 環境・防耐火試験部 長 遊佐秀逸様」「ニチアス株式会社建材事業本部常谷雅彦様」 に深く感謝致します。

\section{参考文献}

1）森直樹他 “乾式系吹付けアスベストの無人化除去・回収システムの開発（そ の1）システム概要、及び実証試験結果” 日本建築学会大会学術講演梗概集A1、 p 581-582、2007年8月

2）大山能永他 “乾式系吹付けアスベストの無人化除去・回収システムの開 発 (その2) 作業環境の検討” 日本建築学会大会学術講演梗概集A1、p 583-584、 2007 年 8 月

3）森直樹他 “遠隔操作による乾式系吹付けアスベスト除去ロボットの開発” 日本建築学会建築生産自動化小委員会、第 17 回建築施工ロボットシンポジウ 么予稿集、 p 9-14、2008 年 3 月 13 日

[2008年 6 月19日原稿受理 2008年 8 月 5 日採用決定］ 